\title{
A formação de núcleos urbanos no Brasil Colônia: procedimentos para elevar freguesias a vilas na Capitania de São Paulo na segunda metade do século XVIII
}

\author{
SALGADO, Ivone ${ }^{1}$ \\ PEREIRA, Renata Baesso ${ }^{2}$
}

1POSURB, PUC Campinas - SP, Brasil. salgadoivone@puc-campinas.edu.br 2POSURB, PUC Campinas - SP, Brasil. renata.baesso@puc-campinas.edu.br

\section{Resumo}

As instituições municipais foram instrumentos essenciais na consolidação e defesa dos territórios coloniais. Durante o governo de Dom Luís Antônio de Souza Botelho Mourão (17651775), o poder da Coroa na capitania de São Paulo se fortaleceu, a partir de ações militares, da produção de açúcar para exportação e da criação de uma rede de núcleos urbanos. Seus sucessores buscaram aprimorar estruturas que garantiriam os fluxos de pessoas e mercadorias no território e consolidar suas fronteiras. $\mathrm{O}$ trabalho é uma análise comparativa das práticas e discursos envolvidos na elevação de três freguesias a vila, em 1797, pelo Governador da capitania, Castro e Mendonça (1797-1802): Jaguary, Campinas e Araraytaguaba pertencentes às vilas de Atibaia, Jundiaí e Itu. $\mathrm{O}$ trabalho demonstra que as elevações respondem a diferentes estratégias de consolidação do território e fundamenta-se na documentação primária que representa os instrumentos de controle do território e do espaço urbano pela Coroa: cartografia, relações de população e ofícios das Câmaras e dos Governadores. O trabalho elucida o processo de constituição das vilas no território paulista no final do século XVIII, destacando o papel dos agentes do poder e demonstrando que o rito fundacional foi determinante na configuração espacial dos núcleos urbanos em questão.

Palavras-Chave: Capitania de São Paulo, freguesias, elevação de vilas, forma urbana, desmembramentos territoriais, segunda metade do século XVIII.

\begin{abstract}
Municipal institutions were essential tools in the consolidation and defense of the territories of the Portuguese Crown in Brazil. During the government of Don Luis Antonio de Souza Botelho Mourão (1765-1775), the power of the Crown in the captaincy of São Paulo has strengthened, from military actions, sugar production for export and the creation of a network of urban centers. His successors sought to improve the structures that would ensure the flow of people and goods within the territory and consolidate their borders. This paper is a comparative analysis of practices and discourses involved in the elevation of three parishes to the status of town in 1797 by the then Governor of the captaincy Castro e Mendonça (1797-1802): Jaguary, Campinas, Araraytaguaba belonging to Atibaia, Jundiaí, and Itu. The research demonstrates that each elevation responds to a strategy of the consolidation of the territory. The case studies were based on primary documents that represent the Crown's control instruments of the territory: cartography, relations of population and official correspondence of Governors and of the Chambers of the towns. The work elucidates the processes of urban creation in São Paulo in the late eighteenth century, highlighting the role of the Crown's agents, and demonstrating that the uses of legal and regulatory mechanism were crucial to establish attributes of urbanity in these towns.
\end{abstract}

Key-Words: Captaincy of São Paulo, parishes, town elevations, urban form, territorial dismemberments, late eighteenth century. 


\section{Introdução: A historiografia sobre a fundação de núcleos urbanos na Capitania de São Paulo}

Quando a Coroa portuguesa iniciou a colonização efetiva do Brasil, procurou transferir para a colônia o mesmo modelo de organização municipal vigente no Reino no século XVI. A historiografia sobre o tema tem demonstrado que as instituições municipais foram instrumentos essenciais para a consolidação e defesa dos territórios ultramarinos. A Vila de São Paulo, primeira municipalidade instituída no interior da colônia (1558), tornou-se porta de acesso ao sertão. Ao longo dos caminhos que conduziam às regiões de captura de indígenas, e daqueles que permitiriam o acesso às áreas produtoras de metais preciosos, foram fundados vários povoados (REIS, 2013) Os paulistas tiveram um papel estratégico na ocupação deste território, mas a partir do final do século XVII, a capitania de São Paulo passa por um período de decadência, decorrente da descoberta de ouro na região das Minas Gerais, ocasionando a migração das suas forças produtivas e a consequente perda da sua autonomia política em 1748. A capitania de São Paulo só seria restaurada em 1765.

Os trabalhos de Nestor Goulart Reis (REIS 2000; REIS, 2001; REIS, 2013) e Roberta Max Delson (DELSON, 1997) são marcos historiográficos sobre a fundação de núcleos urbanos no Brasil no século XVIII. Tais estudos explicam que parte destas fundações estavam vinculadas à estratégia de ocupação e definição das fronteiras do eixo centro-sul da colônia, inscrita na política mercantilista ilustrada do Marquês de Pombal, então primeiro ministro de Portugal.

Para Nestor Goulart Reis, a política urbanizadora, entendida como conjunto de critérios para controlar o processo de urbanização, é parte essencial da política colonizadora da Coroa Portuguesa. Do ponto de vista da ocupação do território, a política pombalina teve como principais ações o fortalecimento do poder da Coroa contra alguns interesses do catolicismo jesuítico e da nobreza, através da expulsão dos religiosos da ordem dos domínios portugueses e da extinção das donatarias; a definição e preservação das fronteiras brasileiras a partir da ocupação da hinterlândia por um sistema de cidades, vilas e povoações; e a transferência do Governo Geral do Brasil de Salvador para São Sebastião do Rio de Janeiro em 1763.

No que diz respeito à Capitania de São Paulo, as instruções de governo enviadas pelo Marquês de Pombal e dirigidas ao vice-rei, sediado no Rio de Janeiro e a D. Luís Antonio de Souza Botelho Mourão, o Morgado de Mateus, capitão-general e governador da capitania (1765-1775), ordenavam a construção de uma estratégia de consolidação territorial, animação econômica e fortalecimento do poder central da Coroa na colônia. A implantação dessa política colonizadora pretendia romper com o quadro de despovoamento do território paulista e se deu através da inauguração da produção de açúcar voltada para o comércio metropolitano, articulada à produção de subsistência de uma rede de povoados, freguesias e vilas.

A obra de Heloísa Liberalli Bellotto esclareceu as principais ações do Morgado de Mateus a partir de 1765:

(...) às diretrizes estabelecidas por Pombal - marca comum em toda a sua política ultramarina - D. Luís Antonio teria juntado, com objetividade, a sua intuição e sua inclinação dinâmica por realizar, na capitania que Ihe cabia restaurar, um governo progressista. "Acrescentar as povoações, estender os domínios, fertilizar os campos, estabelecer fábricas, idear novos caminhos, penetrar sertões incógnitos, descobrir ouro, fortificar Praças, armar o Exército e fazer observar as leis" foram os propósitos que se dispôs a cumprir, em simbiose com a determinação máxima da metrópole de combater o inimigo espanhol (BELLOTTO, 2007, p.313).

A formação de freguesias e vilas na Capitania de São Paulo, a partir da gestão restauradora do Morgado de Mateus, se fez pela 
congregação da população dispersa em povoados, seguindo uma tradição. Como demonstrou Murillo Marx, a complexidade dos processos de formação de núcleos urbanos no período colonial até o século XIX revela uma impressionante constância por séculos e um processo difuso em todo o território da então colônia de Portugal. De acordo com o autor, no Brasil colônia, uma das formas recorrentes de formação de povoados era a partir da doação de terras por um morador, ou conjunto de moradores, ao patrimônio de um santo de devoção da Igreja Católica. Estas terras cedidas passavam a constituir um bem sagrado e sobre elas poderia ser erguida uma capela, proporcionando a formação e expansão de um povoado, e determinando, sobretudo, legitimidade à terra, conforme as ordenações eclesiásticas. À medida que o povoado se desenvolvesse este poderia adquirir o estatuto de freguesia. Quando a freguesia era elevada ao estatuto de vila, a delimitação do rossio e do termo eram fundamentais na ocupação do território e na definição do espaço urbano, distinto do rural. Da mesma maneira, são importantes as relações que este urbano estabelece com o rural e o papel de cada núcleo urbano numa rede regional hierarquizada de povoados, freguesias, vilas e cidades (MARX, 1991)

Em estudo sobre a política de urbanização na capitania de São Paulo, Maria Fernanda Derntl analisou as iniciativas de criação de núcleos urbanos promovidas especialmente no período de administração do Morgado de Mateus (1765 - 1775) e esclarece o processo de elevação de um povoado em freguesia:

A capela deveria ter um patrimônio fundiário próprio e um dote ou patrimônio capaz de assegurar uma renda anual mínima para a sua manutenção. Antes de começar a funcionar, deveria ser inspecionada e consagrada para o culto. A promoção de uma capela à condição de freguesia costumava levar em consideração critérios de ordem econômica e demográfica, embora fatores de ordem política pudessem mesmo ter preeminência. Em geral, os moradores suplicavam a elevação à freguesia alegando encontrarem-se carentes de assistência espiritual devido à distância à sede paroquial e a dificuldades de caminhos. Era necessário que a capela já tivesse sido então transformada em um edifício maior, a igreja matriz. O território onde viviam os fiéis que frequentavam a capela não era delimitado fisicamente. Já as freguesias, depois de fundadas, precisavam ir demarcando seu território à medida que surgissem freguesias confinantes (DERNTL, 2010, p.66).

Já a criação de uma vila implicava a imposição de uma instituição jurídica a um núcleo urbano que se tornava então formalmente integrado ao Império Português. Mais precisamente, caberia falar na criação de concelhos, unidade territorial mínima no âmbito civil, cujo governo estava a cargo de uma Câmara. De acordo com Fonseca, a palavra vila designava inicialmente apenas o principal núcleo de construções onde ficava sediada a Câmara. Mas, como a maior parte dos concelhos tinha sede numa vila - e não numa cidade - as palavras villa e concelho acabaram se tornando sinônimos.

No ato de elevação a vila, atribuía-se a cada um dos concelhos um termo e um rossio. O termo era todo o território de jurisdição da municipalidade, onde podia haver vários bairros e paróquias. O rossio designava os terrenos cedidos pela Coroa, por meio de carta foral, para constituir patrimônio da municipalidade. O rossio era de usufruto comum, podendo ser utilizado para pastos, plantações e obtenção de lenha. Servia ainda de reserva para futura expansão da vila, seja para moradia ou para abertura de caminhos e praças. Competia aos edis da Câmara parcelar o rossio e arrendar as datas de terra aos moradores mediante pagamento de um imposto anual, o foro. Este modelo tradicional de organização local do território utilizado pela monarquia portuguesa apresentava pequenas diferenças entre sua configuração no 
Reino e na Colônia (FONSECA, 2011, p.28).

No Brasil Colônia, observa-se ainda que vila e cidade possuem significados diversos. Segundo Fonseca, tanto no Reino, como na Colônia, os concelhos que tinham uma cidade por sede eram raros. O título de cidade era atribuído somente às localidades que exerciam papéis importantes do ponto de vista religioso, político ou militar, não sendo portanto concedido somente às sedes de bispado, mas também, entre outros casos, a povoações litorâneas ou fronteiriças, dotadas de praças-fortes (FONSECA, 2011, p.28). No caso da colônia, a prerrogativa de fundar cidades era exclusiva da Coroa e estas assumiam o papel de cabeças de rede.

\section{As elevações de freguesias ao estatuto de vilas na gestão restauradora de Dom Luís Antônio de Souza Botelho Mourão, Morgado de Mateus (1765-1775)}

Apoiando-se nos dados levantados por Alice Canabrava, Derntl afirma que, em 1766, a capitania de São Paulo era muito extensa, mas na área que está hoje sob jurisdição do estado de São Paulo habitava apenas um quarto dos seus então 63.228 habitantes. Esta área então se estendia até as freguesias de Santo Amaro, Cotia, Guarulhos, Juqueri, Nazaré, Atibaia e Jaguary. Considerando todo o território da capitania, havia 38 freguesias em 1765. Já em 1774, o bispo Dom Frei Manuel da Ressurreição afirmou ter encontrado 53 freguesias e, em 1824, de acordo com um mapa do Bispado de São Paulo, o número chegou a 88 , sendo que muitas localizadas em territórios que hoje não pertencem ao estado de São Paulo (DERNTL, 2010, p. 62-68).

Até 1765 , havia dezoito vilas e uma cidade na capitania de São Paulo. Entre 1765 e 1775, foram instaladas dez vilas, mas muitas delas em território que hoje não pertence a este estado. Dentre as novas vilas criadas entre 1765 e 1775, que hoje pertencem ao estado de São Paulo, estão as de São José da Paraíba (1767), Mogi Mirim (1769), Atibaia (1769), Sabaúna
(1770), Itapetininga (1771), Apiaí (1771) e São Luiz do Paraitinga (1773). Entre 1775 e 1802, foram elevadas as seguintes vilas (hoje no estado de São Paulo): Cunha (1785), Lorena (1788), Nova Bragança (1797, atual Bragança Paulista), São Carlos (1797, atual Campinas) e Porto Feliz (1797).

Segundo Beatriz P. Siqueira Bueno, no final do século XVIII, a Capitania de São Paulo englobava o atual estado do Paraná, parte de Santa Catarina e do Rio Grande do Sul, apresentando um conjunto de 34 núcleos urbanos elevados à categoria de vila, e uma cidade - São Paulo. Na formação destes núcleos urbanos, é possível observar que:

A maioria passou por estágios anteriores, como capela e freguesia antes de ser elevado à categoria de vila. Tal lógica de desmembramento municipal esteve vigente em todo o Brasil, implicando na perda de território (i.e. do termo) por parte da celula mater, certamente envolvendo conflitos de interesses nesses momentos (BUENO, 2009, p. 259).

Uma das principais estratégias do governo do Morgado de Mateus consistiu no plano de defesa militar da fronteira ocidental da capitania de São Paulo, através da fundação da Fortaleza de Nossa Senhora dos Prazeres do Iguatemy (Figura 1), fortificação esta localizada na atual divisa com o Paraguai (próxima ao município de Amambaí - MS). Esta Praça do Iguatemy situava-se em região que começara a ser ocupada após a descoberta das minas de Cuiabá. Constituía-se em uma instalação militar que, assim como os núcleos de povoamento oficiais, foi criada para proteger os acessos fluviais às áreas de mineração. A ocupação desta região intensificou-se a partir dos tratados de demarcação de limites estabelecidos entre as coroas portuguesa e espanhola, especificamente o Tratado de Madrid, em 1750.

O processo de fundação da Villa dos Prazeres de Nossa Senhora do Iguatemy é revelador da manutenção da tradição do governo português na fundação de núcleos urbanos na sua colônia, bem como do papel dos quadros técnicos no 
processo de demarcação de suas fronteiras. As atividades de demarcação da fronteira com os espanhóis na Capitania de São Paulo contavam com quadros técnicos de alto nível, como foi o caso do engenheiro militar português José Custódio de Sá e Faria.

Figura 1: Planta da Praça de Nossa Sra. dos Prazeres do Rio Iguatemy (folha 56/66). ZUZARTE, Teotônio José, 1769. Plano em borrão de todos os rios, e todas as caxueyras, e todas as cousas mais notaveis que vi desde o Porto de Araraytaguaba até a povoação de Guatemy (...). Fonte: Biblioteca Nacional, Acervo digital.

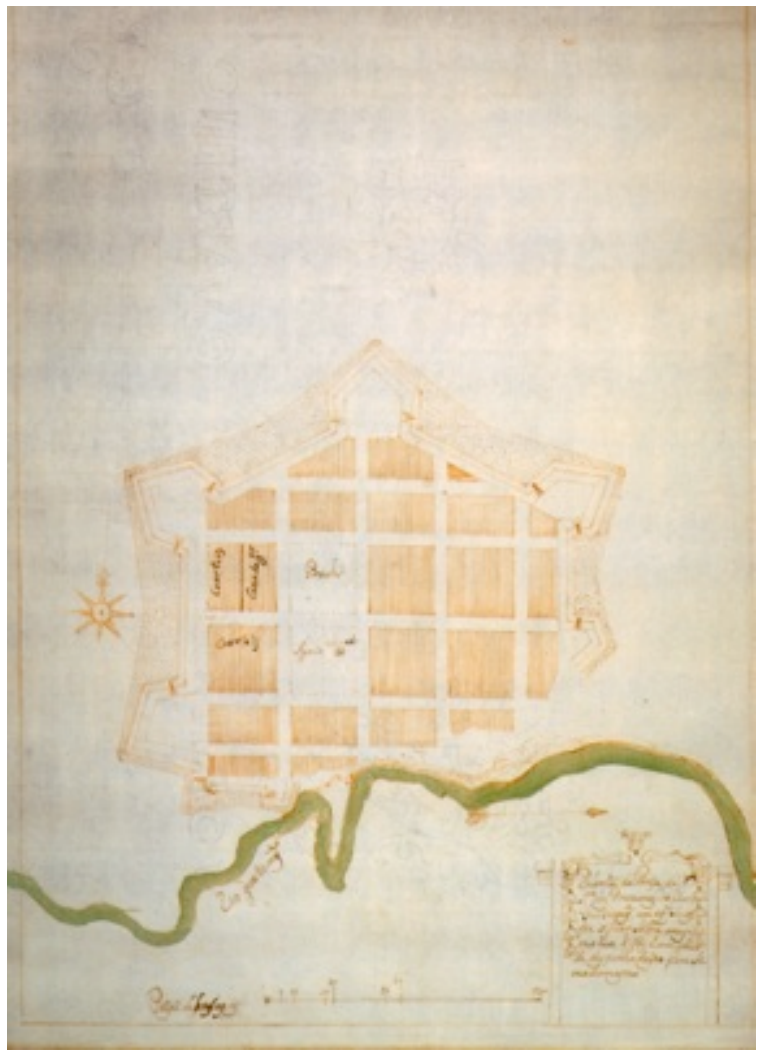

Com o objetivo de erigir em vila a Povoação e Praça de Nossa Senhora dos Prazeres do Rio Iguatemy, em 27 de outubro de 1770, Dom Luís Antonio de Souza Botelho Mourão envia uma ordem ao Capitão-mor Regente, o Tenente Coronel João Miz Barros, acompanhada de um documento denominado "Ordem para se fundar Villa na Povoação e Praça dos Prazeres de Guatemy", que deveria orientar os seus procedimentos. Neste documento, fica clara a intenção do governador em elevar aquela povoação à vila, assim como sua preocupação com os vizinhos espanhóis:
Como me persuado que o estabelecimento dessa Povoação e Praça se acha já em estado de se poder conservar e subsistir; ainda que, pela disposição em que se acha e pela qualidade das pessoas, que atualmente tem de guarnição e não deixarão de fazer uma rigorosa defensa, dando tempo conveniente para se poder socorrer, me parece que será muito útil, para efeito de radicar mais esses Povos, 0 pensamento de haverem de prevalecer nessas terras, de erigir esta Povoação em Villa, e no caso em que você e os mais oficiais, que the parecer consultar, concordarem nesta minha determinação, remeto as ordens necessárias para você poder mandar Levantar Pelourinho, nomear os oficiais da Câmara; e que tudo porem se deve fazer por aquele modo mais sucinto que for possível em ordem a não causar maiores ciúmes aos nossos vizinhos, e conservar com eles aquela paz e sossego que tanto desejo (Dom Luiz Antonio de Souza, 1770. Apud ARQUIVO DO ESTADO DE SP, 1894, p.130. Grifos nossos).

Levantado o pelourinho, símbolo do poder civil na nova vila, as pessoas mais capazes seriam nomeadas para juízes, escrivão, vereadores e procuradores do Concelho e serviriam por todo o ano de 1771, fazendo que se praticasse o que se costumava praticar em semelhantes ereções de vilas.

O governador argumentava que, segundo as ordens reais que recebera nas instruções de 26 de janeiro de 1765 , e em outras, que recebera na sequência, seria muito conveniente ao serviço real que na Capitania de São Paulo se originassem vilas naquelas partes que fossem mais próprias e que nelas se congregassem os "vadios" e dispersos, ou aqueles que viviam em sítios volantes, para morarem em povoações civis, nas quais se pudessem administrar os sacramentos. Segundo o governador, como a povoação de Nossa Senhora dos Prazeres de Iguatemy era lugar "acomodado" para se levantar em vila, porque já se achava com bastante número de moradores, assim como de 
casas, e estas eram "bem arruadas", ordenava tal providência. Para este efeito, ele encaminhou um documento denominado "Extracto para se formar Villa" que deveria orientar a fundação de vilas na capitania:

Extrato para se formar Villa. Auto de fundação, e estabelecimento da nova villa de tal que erigiu Fulano por ordem que teve do $\mathrm{III}^{\mathrm{a}} \boldsymbol{\&}^{\mathrm{a}}$ Anno de Nascimento $\boldsymbol{\&}^{\mathrm{a}}$, nesta nova Povoação de tal aonde veyo Fulano comigo escrivão adiante nomeado, e tendo presentes os Povoadores, que nela se achavam, logo pelo dito Fulano foi dito que ele trazia uma Portaria do $1 \mathrm{Im}^{\circ} \mathrm{e}$ Excm $^{\circ} \&^{\circ}$ cujo teor é o seguinte: (vai copiada a Portaria de verbo adverbum) Em virtude da qual mandou apregoar em altas vozes pelo Porteiro Fulano, que ali se pretendia formar Villa, para se poder administrar a justiça a aqueles Povoadores, por ficarem muito distantes da vlla de tal, a que eram e tinham sido até aquele tempo sujeitos; a qual fundação se fazia pelo aumento e perpetuidade daquele Lugar, para prova do que já se achava principiada Igreja para nova Freguesia o que indicava a duração, que teria o mencionado Lugar, e de como se fundou a dita nova villa, mandou o dito Fulano fazer este auto, em que assinou com todos os moradores dela, que presentes se achavam, e o Porteiro Fulano, e eu Fulano escrivão que o escrevi - vão os nomes dos que se assignaram (Dom Luiz Antonio de Souza, 1770. Apud ARQUIVO DO ESTADO DE SP, 1894, p.127-8. Grifos nossos).

A portaria remete a um procedimento normativo para se fundar vila no Brasil Colonial na segunda metade do século XVIII. Os três estudos de caso de elevação de freguesias à condição de vilas na gestão de Antonio Manoel de Mello Castro e Mendonça, governador da capitania de São Paulo entre 1797 e 1802, apresentados a seguir, revelam a continuidade desses processos em gestões subsequentes. Trata-se de um procedimento padronizado, que se iniciava com a apresentação, por parte dos moradores, de uma petição, encaminhada ao governador da capitania, na qual estavam expostas as razões que fundamentavam o pedido pela emancipação.

\section{A elevação a vila das freguesias de Jaguary, Nossa Senhora da Conceição das Campinas do Matto Grosso de Jundiaí e Ararytaguaba na gestão do governador da capitania de São Paulo, Antonio Manoel de Mello Castro e Mendonça (1797- 1802)}

Antonio Manoel de Mello Castro e Mendonça foi nomeado governador da capitania de São Paulo (1797-1802) por decreto da rainha D. Maria I, como premiação pela qualidade dos serviços por ele prestados como Capitão da Infantaria das Ilhas dos Açores, além de influências de sua família junto a Corte (GARRIDO, 2012, p.46).

As cartas remetidas pelo Governador ao Secretário de Estado, D. Rodrigo de Souza Coutinho, documentam suas principais ações e a maneira como eram atendidos os desígnios dos seus superiores. Na carta de 17 de agosto de 1797, Castro e Mendonça se compromete a adotar "as medidas e o sistema de governo de seu antecessor", Bernardo José Maria Lorena e Silveira (1788 e 1797), no sentido de "promover a felicidade destes povos", de acordo com as instruções enviadas em 1796 (CASTRO E MENDONÇA,1797. Apud ARQUIVO DO ESTADO DE SP, 1899, p.3).

O Relatório elaborado pelo Capitão General Bernardo José de Lorena descreve o estado da capitania na passagem do governo ao seu sucessor, bem como os principais instrumentos de controle da sua administração: o Mapa Corográfico da Capitania - elaborado pelo Ajudante Engenheiro Antonio Rodrigues Montezinhos em 1792 - no qual estavam descritos os limites, com as capitanias confinantes e com os domínios da Espanha; e as Relações dos Habitantes que eram remetidas anualmente. Com relação à agricultura, Bernardo José de Lorena destaca um progresso muito grande: a Vila de Itu produzia mais de cinquenta mil arrobas de 
açúcar por ano e nas freguesia de Araraytaguaba e de Campinas, bem como na povoação de Piracicaba, também já se produzia muito açúcar. Por todo o litoral da capitania, e principalmente em Paranaguá havia farta produção de arroz, farinha de mandioca, e goma (LORENA E SILVEIRA, s.d. Apud ARQUIVO DO ESTADO DE SP, 1895, p.121).

Já no seu primeiro ano de governo da Capitania de São Paulo, em 22 de novembro de 1797, Castro e Mendonça enviou correspondência ao Secretário de Estado, Dom Rodrigo de Souza Coutinho, informando sobre algumas medidas tomadas que visavam responder às instruções que este lhe havia enviado, em 24 de julho do mesmo ano. Nesta, Castro e Mendonça destacava os propósitos do rei de Portugal, que pretendia, em seus vastos domínios, aumentar a riqueza e ordenava, no empenho de obter tais fins, promover o maior aumento do comércio e a permuta recíproca dos gêneros e manufatura entre o reino e a Capitania de São Paulo. Para alcançar tal objetivo, deveria o governador animar o uso de vinhos, azeite, etc. e favorecer as pessoas que consumissem maior quantidade destes produtos. O governador informava ainda que, havia procurado, de todos os meios lícitos, animar a agricultura e o comércio e que havia promovido a elevação de quatro freguesias à condição de vila, Antonina, Porto Feliz, Nova Bragança e São Carlos; e ainda, que pretendia promover a elevação de duas povoações à condição de freguesia, Bananal e Piracicaba:

"Tenho animado as povoações criando já quatro Villas novas. $1^{\mathrm{a}}$ a Freguesia do Pillar, Porto de mar junto a Paranaguá, de mais de duas mil e trezentas almas, e que com atenção a ser a primeira Villa que se eregia depois do feliz Nascimento de S. Alteza o Príncipe D. Antonio, lhe puz o nome de Villa Antonina: - $2^{\mathrm{a}}$ a Freguesia de Ararytaguaba, termo de Villa de Itú com trez mil e seis almas de população, a qual por ficar na margem do Rio Tieté, onde se embarca para as Minas do Cuyabá, Matto Grosso, e Iguatemy e mandei intitular Porto Feliz: - $3^{a}$ a Freguesia de Jaguary, termo da Villa de Atibaya, e confinante por hora, com a capitania de Minas Gerais, de quatro mil quatro centos e quarenta e seis pessoas de confissão, a que denominei Nova Bragança: - $4^{\mathrm{a}}$ a Freguesia das Campinas, termo da Villa de Jundiahy, com duas mil cento e sete pessoas de confissão, a qual por ser ereta no dia 4 do presente mes, o primeiro, em que se festejava aqui o feliz Nascimento da sereníssima Senhora Infanta a fiz intitular Villa de São Carlos, e já os Ouvidores das respectivas comarcas as farão erigir para os Camaristas entrarem a servir do $1^{\circ}$ de Janeiro de 1798 em diante. Pretendo igualmente erigir em Freguesia a Povoação do Bananal, por ficar no caminho do sertão que segue desta capitania para a do rio de Janeiro, e a de

Piracicaba lugar com todas as disposições para vir a ser uma Povoação florescente pela qualidade do seu solo, e estar situada no Rio do mesmo nome, que a poucos dias de viagem vai desaguar no Tietê." (CASTRO E MENDONÇA,1797. Apud ARQUIVO DO ESTADO DE SP, 1899, p.67).

Cada elevação respondia a uma estratégia de consolidação do território já delineada no governo do Morgado de Mateus: o litoral sul era sempre uma área vulnerável às aproximações espanholas e a elevação da vila de Antonina visava consolidar a colonização da baía da Paranaguá (BELLOTTO, 2007, p.160); Jaguary, pertencente a Vila de Atibaia, estava na área de conflitos de fronteiras com a Capitania de Minas; Campinas pertencente a vila de Jundiaí, situada no caminho para as minas de Goiás, e Araraytaguaba, pertencente a vila de Itu, eram importantes freguesias produtoras de açúcar, sendo esta última um porto do Rio Tietê, no caminho para a fronteira com territórios da Espanha. As figuras 2 e 3 demonstram a localização das freguesias elevadas a vila por Castro e Mendonça e suas posições estratégicas em relação aos caminhos e divisas com a Capitania de Minas Gerais.

Figura 2: Carta elaborada pelo Major Umbelino Alberto de Campo Limpo (1869) a partir do original: 
"Carta Chorographica da Capitania de São Paulo, em que se mostra a verdadeira cituação dos lugares por onde se fizerão as sete principaes divizoens do seu governo com o de Minas Geraes, 1766". Fonte:< http://www.novomilenio.inf.br/santos/mapa41g.htm > Acesso em: 21 de outubro de 2014.

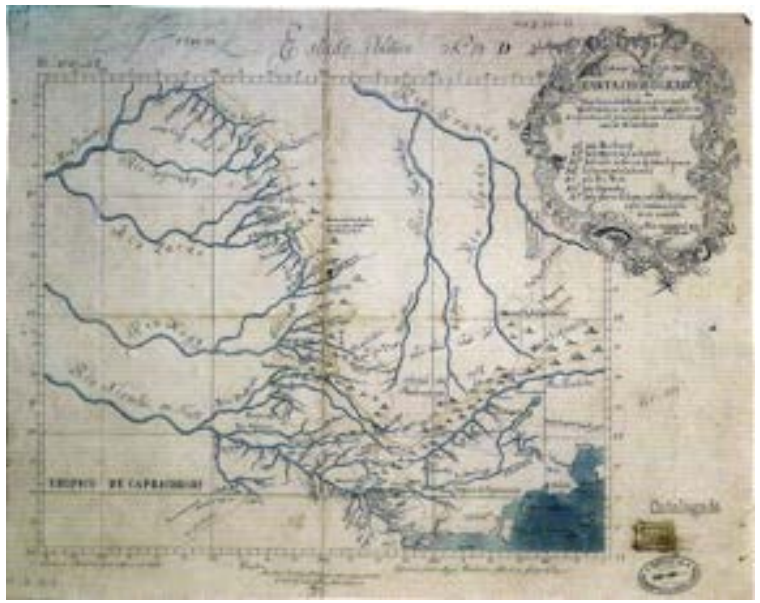

Figura 3: Localização das freguesias (verde) elevadas a vila por Castro e Mendonça em 1797: Campinas, Jaguary e Ararytaguaba desmembradas respectivamente das vilas de Jundiaí, São João de Atibaia e Itu (vermelho). Detalhe da figura 2 manipulada pelas autoras.

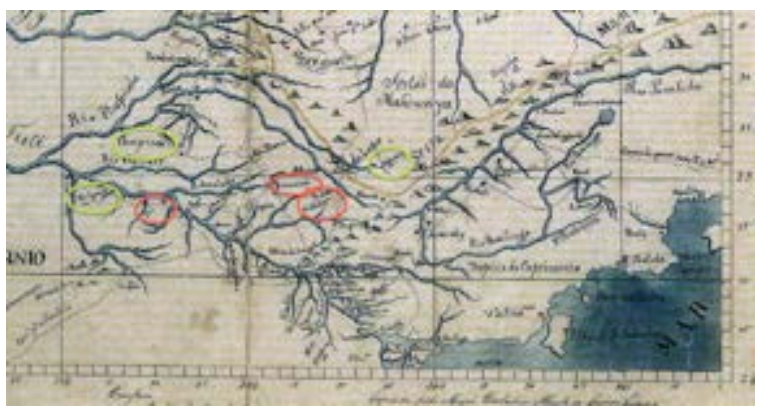

Segundo Petrone, na segunda metade do século XVIII, o modo paulista de fabricar açúcar, diferente dos grandes empreendimentos nordestinos e fluminenses, estabeleceu um novo desenho fundiário para a capitania de São Paulo: "a organização da fazenda em terra obtida por posse ou sesmaria, instalações modestas e pequeno número de escravos, teria possibilitado o desenvolvimento da cultura da cana-de-açúcar e o enorme acúmulo de capitais que permitiriam a expansão desta atividade." A partir dessa estratégia, constitui-se o território que Petrone define como "quadrilátero paulista do açúcar", formado pelas vilas de Sorocaba, Piracicaba, Mogi-Guaçu e Jundiaí e que se articulavam, através de uma rede de caminhos secundários, ligados às estradas bandeiristas do Viamão e das Minas dos Goyazes (PETRONE, 1968, p.90). A cidade de São Paulo interligava os centros produtores do açúcar do oeste da capitania ao Porto de Santos, através do Velho Caminho do Mar pavimentado durante o governo de Bernardo José de Lorena. Na última década do século XVIII, a relevância da economia do açúcar no "quadrilátero paulista" é tal que as demandas pela emancipação das freguesias de Araritaguaba e Campinas obtém êxito.

\section{Os procedimentos para a elevação de uma freguesia a vila}

No final do século XVIII, na Capitania de São Paulo, a cerimônia de elevação de uma freguesia em vila seguia uma série de procedimentos normatizados por documentos oficiais: tendo sido autorizado pelo governador da capitania a fundação da vila, em resposta à "Petição do Moradores", o ato fundacional principiava pelo "Auto de Erecção", seguido dos "Termo de Levantamento de Pelourinho" e "Termo de Escolha e de Demarcação de Terreno para os Paços do Concelho e Cadeya", para em seguida serem estabelecidos o "Termo de Declaração de Rocio" e o "Termo de Divisão de Limites"; e, finalmente, se dava o "Auto de Eleição" para a constituição do novo Concelho.

\subsection{A petição dos moradores}

A elevação de uma freguesia a vila, quando não era diretamente uma estratégia de governo, como foi o caso da fundação da Villa do Prazeres de Nossa Senhora do Iguatemy, em 1770, pelo governador da capitania de São Paulo, Dom Luís Antonio de Souza Botelho Mourão, principiava por uma petição do moradores.

No caso da Freguesia de Ararytaguaba (Fig. 4), que pertencia ao termo da vila de Itu, os seus moradores encaminharam uma representação ao governador na qual procuraram fundamentar o pedido de elevação da freguesia à vila, não só pelo fato de ali já haver "3.006 pessoas de confissam", mas também: 
“ (...) por ser um Porto frequentado de Comerciantes das minas de Cuyaba, e Matto Grosso, e de diferentes expedições de sua Majestade para os vastos sertões, que decorrem da mesma freguesia até a fronteira da cidade de Paraguay da America Espanhola, tendo por isso a capacidade, e disposição para vir a ser em poucos anos uma das vilas opulentas desta Capitania, sendo por outra parte igualmente digno de atenção o incomodo que experimentam muitos daqueles moradores, em ir servir a grande distancia de léguas os empregos públicos da Câmara da Villa de Itu, deixando por isso em desamparo suas casas, famílias, e agriculturas de que vivem, resultando-lhes disso gravíssimos prejuízos." (ALMEIDA (escrivão), 1797. Apud ARQUIVO DO ESTADO DE SP, 1913, p.30).

No caso de Campinas, a petição encaminhada pelo vigário da freguesia, Joaquim José Gomes, em 1797, assinada por 47 "homens bons" da região - a maioria donos de engenhos - que se viam impedidos de se candidatar a cargos da câmara da vila de Jundiaí, apresenta um quadro sucinto do povoamento, número de casas e renda.

"Dizem os moradores da nova freguesia de Campinas do termo da Villa de Jundiahy, que consta do abaixo assinado anexo, que se vem impedidos em servirem os cargos da Republica da dita Villa por morarem distantes da mesma oito, dez, doze e catorze léguas, no que sentem gravíssimos prejuizos nas suas Lavouras por serem senhores de engenhos, quando a freguesia dos suplicntes tem no todo o numero de duas mil cento e sete pessoas, e nos últimos tres anos a esta soma tem acrescido seiscentas e oitenta e oito pessoas se pode atestar pela manifestação de seu pároco anexa; quanto aos fogos há mais de quatrocentos e de rendimento poderá ter a Villa cinquenta mil reis, a cuja atenção recorrem os suplicantes a Vossa Excelência para que, atendendo a esta verdadeira representação, mandar fazer Villa a nova freguesia de Campinas, porque assim podem servir os cargos da Republica, e sem prejuízo de tratarem da sua lavoura." (Joaquim José Gomes - vigário da Freguesia e mais 47 homens bons - 1797. Apud ARQUIVO DO ESTADO DE SP, 1913, p.3)

Figura 4: Planta da Freguesia de Ararytaguaba: Largo da Matriz, casario e os quintais. (folha 2/66). ZUZARTE, Teotônio José, 1769. Plano em borrão de todos os rios, e todas as caxueyras, e todas as cousas mais notaveis que vi desde o Porto de Araraytaguaba até a povoação de Guatemy (...). Fonte: Biblioteca Nacional, Acervo digital.

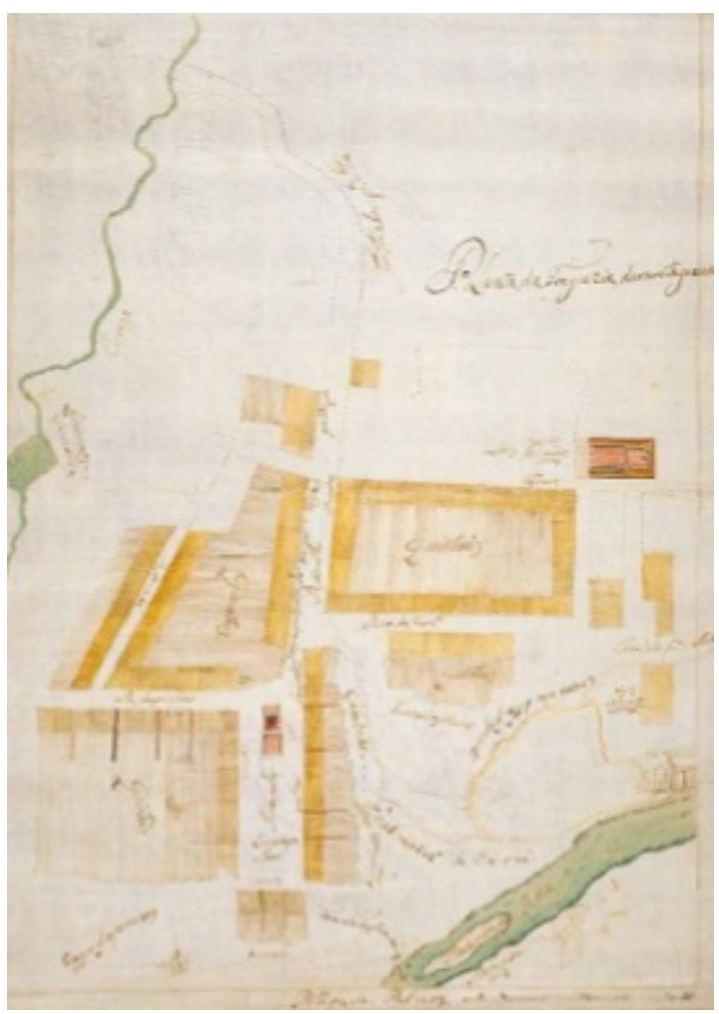

O caso da elevação da Freguesia de Jaguary à condição de Vila de Nova Bragança, revela conflitos entre os moradores da freguesia e a Câmara de Atibaia que não queria perder parte do seu termo. Em 26 de agosto de 1797, o Ouvidor-Geral, Caetano Luiz de Barros, encaminha ao Governador Castro e Mendonça, uma petição, assinada por 78 moradores da Freguesia de Jaguary, no termo da Villa de São João de Atibaya, requerendo elevar à condição de vila a dita freguesia. Nesta petição, os moradores apresentam assim suas motivações: 
que a freguesia era populosa e compreendia 1.106 fogos com 4.446 pessoas; que muitos crimes ali praticados ficavam impunes por ser a freguesia confinante com Minas Gerais para onde fugiam os criminosos antes da notícia chegar a Atibaia; que os moradores da freguesia eram obrigados a exercer os cargos da República em Atibaia em detrimento do cuidado de suas lavouras, famílias e casas; que os seus últimos moradores ficavam em Mogi e Ouro-fino de Minas, a oito e dez léguas da freguesia, respectivamente, e esta ficava distante 4 léguas da Villa de São João de Atibaya, não podendo a justiça prestar a tempo suas obrigações. Estes fregueses pediam então que, diante do exposto, e por considerarem haver naquela freguesia "Homens capazes de servirem aos cargos da República e se obrigarem a fazer Cadeia, e o mais concernente a boa administração da justiça", fosse deferida a solicitação (Assinam os homens bons da freguesia, 1797. Apud ARQUIVO DO ESTADO DE SP, 1904. p. 98-9)

A Câmara da Villa de São João de Atibaya tomou conhecimento da intenção de emancipação dos moradores da Freguesia de Jaguary e, no dia $1^{\circ}$ de outubro de 1797 , representada pelo Juiz Francisco Xavier Cesar e por demais membros da câmara, encaminhou ao Ouvidor Geral e Corregedor da Comarca uma manifestação contrária à petição dos moradores de Jaguary. Nesta, a Câmara de Atibaia apresenta vários argumentos. Após fazer um balanço sobre as despesas e receitas do Concelho da I, concernente aos anos de 1789 a 1797, concluem os vereadores que não havia receita suficiente para formar nova Casa de Câmara e Cadeia. No balanço do ano de 1797, por exemplo, de uma arrecadação de 316 mil reis, 110 mil reis eram provenientes de Jaguary e no ano de 1766 , de um total de arrecadação de 269 mil e 600 reis, 101 mil e 600 reis eram provenientes de Jaguary. Os dados evidenciam que a Freguesia de Jaguary era responsável por boa parte da arrecadação da Villa de São João de Atibaya, o que justifica o anseio de emancipação de seus moradores. Mas, pelos mesmos motivos, os vereadores de Atibaya resistiam e procuravam desqualificar os moradores de Jaguary, argumentando que estes não poderiam ser compelidos a servir aos cargos da República, pois tratava-se de: " um povo grosseiro, sem cultura, nem civilidade, são raros os que sabem ler e escrever, (...) o maior corpo daquele Povo são oriundos do gentio da terra, bastardos, mulatos, e gente de ínfima plebe" (Câmara de Atibaia, 1797. Apud ARQUIVO DO ESTADO DE SP, 1895, p. 106).

Embora naquela época houvesse 1.106 fogos na Freguesia de Jaguary, os vereadores da Câmara da Villa de São João de Atibaya, que se opunham à sua emancipação, argumentavam ser o núcleo urbano da freguesia, ao qual eles denominaram "capital", muito pequeno, com apenas 25 fogos. Descrevem os seus moradores relacionando suas profissões, dentre eles sapateiro, ferreiro, seleiro e mestre de taipas; e assinalam a existência de pessoas muito pobres entre os moradores da freguesia:

"Tem a capital de Jaguary vinte e cinco fogos existentes a saber: o R.do Coadjutor, o Alferes Aleixo Correa da Cunha, Manoel Rodrigues Freira que ambos sam Dizimeiros, o alferes José Paes da Sylva official de sapateiro, e selleiro, cujos officios se desligará por falta de visita, e que vive hoje de lavouras, Capitam José Pedroso Pinto official de seleiro, e dizem que também tem loja de fazenda seca, o Alferes Joam de Almeyda, velho e muito doente, por cuja cauza largou o Sitio, e veyo para aquele ARayal, Francisco Pinto official de Ferreyro, Joachim Gomes de Moraes Taverneyro, hum carapina que de fora foy para fazer a obra da Igreja, Vicente Gomes Sapateyro, Ignacio, bastardo sapateyro em cujo fogo mora também o Vintenario Francisco Luis Penna José Teixeyra das Neves mestre de taypas, Rosa Domingues, mulher branca, solteira e pobríssima, Maria de Nazareth cazada que vive separada de seu marido, Miguel Dias Cortes homem branco, cazado e pobríssimo, Anna Maria de Tolledo viúva e pobre, 
Genoveba de tal branca e pobre, Ana de tal aleijada, Quiteria escrava com taberna, Joam Leme bastardo sego, Maximiano Nunes e Joachim Nunes, ambos pobres." (Câmara de Atibaia, 1797. Apud ARQUIVO DO ESTADO DE SP, 1895, p. 105-6, grifos nossos)

O Governador Castro e Mendonça, em portaria de 17 de outubro de 1797, ordenava que se fizesse erigir a povoação em vila, com a denominação de Nova Bragança, levantando ali pelourinho, assinalando-lhe o termo, assim como os terrenos para os paços do concelho e para cadeia; e por fim, que procedessem à eleição dos juízes, vereadores e procurador da câmara. Para tal, mandava publicar um edital. No dia 29 de novembro do mesmo ano, este edital foi publicado em local público na Freguesia de Jaguary (Vicente Ferreira e Almeida, escrivão, 1797. Apud ARQUIVO DO ESTADO DE SP, 1895, p. 112).

Na portaria expedida pelo Governador Castro e Mendonça, publicada em praça pública na Freguesia de Jaguary, no dia 29 de novembro de 1797, são expostas as razões pela quais ele havia atendido à solicitação dos moradores da Freguesia de Jaguary, contrariando os interesses dos vereadores da Villa de São João de Atibaya. Além de destacar o fato da freguesia possuir um número expressivo de moradores, 4.446 habitantes, argumentava o governador que aquela povoação era frequentada por comerciantes em direção à Capitania de Minas Gerais, "tendo por isso toda a capacidade e disposição para vir a ser em poucos annos huma das mais opulentas desta Capitania"; concordando com os argumentos dos moradores de Jaguary, afirmava que de fato era incômodo terem que se deslocar até a Villa de São João de Atibaya para servir aos cargos públicos; assim como o fato de estarem afastados da justiça, facilitava que os criminosos ficassem impunes e fugissem para as terras de Minas Gerais. No mais, o governador argumentava que estava procedendo conforme as Instruções Régias de 26 de janeiro de 1765, e outras ordens posteriormente dirigidas aos governadores $\mathrm{e}$ capitães gerais sobre a criação de vilas. Determinou, então, que a Freguesia de Jaguary fizesse "erigir a sua povoação em Villa", cuja denominação seria Nova Bragança, devendo ali ser levantando o pelourinho e ser delimitado o seu termo. Os autos desta delimitação deveriam ser remetidos às câmaras confinantes e deveria ser demarcado o lugar e terreno para os "Paços do Concelho e Cadeya", procedendo à eleição dos juízes, vereadores, e demais oficiais da câmara (Vicente Ferreira e Almeida, escrivão, 1797. Apud ARQUIVO DO ESTADO DE SP, 1895, p. 115).

\subsection{O Auto de Ereção da Vila}

Os procedimentos adotados pelo governador Antonio Manoel de Melo e Castro Mendonça para elevar povoações ao estatuto de vila, no território paulista, são similares àqueles estabelecidos pelo governo de D. Luís Antonio de Souza Botelho Mourão. Percebe-se portanto uma continuidade da política colonizadora ilustrada do período pombalino, que se estende durante a gestão de D. Rodrigo de Souza Coutinho, o Conde de Linhares.

O ato de fundação da nova vila era uma cerimônia que, geralmente, ocorria num único dia, com vários procedimentos, sequencialmente planejados, que se desenrolavam na presença de membros do concelho da vila principal, da qual se desmembraria a freguesia em questão, e na presença dos moradores da freguesia que estava se emancipando.

O processo de elevação da freguesia ao estatuto de vila se fazia no final do século XVIII, na Capitania de São Paulo, por meio do chamado "Auto de Ereção", um rito em conformidade com as Instruções Régias de 1705 e com outras ordens posteriormente dirigidas aos Governadores e Capitães Gerais da Capitania, conforme vimos no documento do governador D. Luís Antonio de Souza Botelho Mourão, encaminhado em 1770 ao Iguatemy.

A portaria que elevava a Freguesia de Nossa Senhora da Conceição das Campinas do Matto Grosso de Jundiaí à Villa de São Carlos foi publicada em 13 de dezembro de 1797, consistindo na apregoação em "altas vozes", na lavração do auto no "livro da Erecçam" e na demarcação do Pelourinho, em 14 de dezembro 
de 1797, seguida da demarcação do Rocio e dos limites da vila no dia seguinte.

$\mathrm{Na}$ elevação da Freguesia de Ararytaguaba à Villa de Porto Feliz, que ocorreu em 22 de dezembro de 1797, o Ouvidor Geral e Corregedor da Comarca de São Paulo, Caetano Luiz da Barros Monteiro, se dirige à freguesia de Ararytaguaba para presidir os ritos.

No caso da elevação da Freguesia de Jaguary à condição de Villa de Nova Bragança, esta cerimônia foi realizada em dois dias distintos. No dia 29 de novembro de 1797, reuniram-se, em praça pública na própria freguesia, os oficiais da Câmara da Villa de São João de Atibaia e os moradores da Freguesia de Jaguary, com a presença do Ouvidor Geral e Corregedor da Comarca de São Paulo, Caetano Luiz de Barros Mendonça e o escrivão a seu cargo, Vicente Ferreira de Almeida. Foi apregoado "em altas vozes", pelo porteiro José Garcia da Rocha, que se erigia a dita povoação em Villa, com o nome de Nova Bragança, em seguida foi lavrado o "Auto de Ereção" no livro específico que foi assinado pelos oficiais da Câmara da Villa de São João de Atibaia e demais moradores da freguesia presentes, somando 34 signatários, dentre eles o escrivão e o ouvidor geral.

A elevação de uma freguesia à categoria de vila era justificada por questões estratégicas e de povoamento. No caso da freguesia de Ararytaguaba, então pertencente ao "termo" da vila de Itu, o governador da capitania, manifestou-se favorável à petição dos moradores, ordenou a publicação de um edital para que se fizesse erigir a povoação em vila e, para tal, que se levantasse ali o pelourinho, se assinalassem os terrenos para o Paço do Concelho e Cadeia, e que fosse delimitado o termo da nova vila. Por fim, deveria se proceder a eleição dos juízes e demais oficiais da câmara. O edital foi publicado em outubro de 1797, o ato de elevação ocorreu no dia 22 de dezembro do mesmo ano e a nova câmara passou a governar a vila em janeiro do ano seguinte, 1798.

\subsection{Os Termos de Levantamento do Pelourinho e de escolha de lugar para o Paço do Concelho e Cadeia}

Após ser "apregoado" em praça pública que aquela freguesia estava erigida em vila, os seguintes procedimentos eram, por tradição, conforme as determinações régias, cumpridos: estabelecimento do "Termo de Levantamento de Pelourinho", sinal de jurisdição da vila; e estabelecimento do "Termo de Escolha e de Demarcação de Terreno para os Paços do Concelho e Cadeya". Tradicionalmente, a "Casa de Câmara e Cadeia" constituía-se num único edifício, um sobrado no qual se instalava a câmara no andar superior e a cadeia no andar térreo. A escolha do terreno onde seria construído o edifício que abrigaria o futuro concelho e a nova cadeia, era geralmente na praça principal onde já estava a igreja matriz e onde se ergueria o pelourinho.

O "Extracto para se formar Villa" de 1770, encaminhado pelo Capitão-Geral e Governador da Capitania de São Paulo, Dom Luís Antonio de Souza Botelho Mourão, para erigir em vila a Povoação e Praça dos Prazeres de Iguatemy, apresenta como procedimentos iniciais na elevação de uma povoação à condição de vila o termo de levantamento do pelourinho e o termo de escolha do local para construir a Casa da Câmara e Cadeia:

"Termo de Levantamento de Pelourinho desta nova villa de tal: Aos tantos de tal mes e anno nesta Povoação de tal aonde achava Fulano com ordem para criar em vila, e sendo aí presentes os Povoadores abaixo assinados, se escolheu a melhor situação, e terreno para se Levantar Pelourinho, em sinal de jurisdição, e logo este se levantou, fazendo-se de um pau de Lei chamado tal, de quatro quinas, com seus brasos de pau, e uma Catana em cima, para se conhecer que era Pelourinho; e logo o dito Fulano mandou apregoar, que se Levantava o dito Pelourinho na referida vila, para que fosse constante a todos; de que para constar mandou fazer este termo, que assinou Com os Povoadores, que presentes se 
achavam, e o Porteiro e eu Fulano escrivão que o escrevi (vão os nomes dos que assinaram)." (Dom Luiz Antonio de Souza, 1770. Apud ARQUIVO DO ESTADO DE SP, 1894, p.128, grifos nossos)

O pelourinho era sinal da jurisdição da vila e, por esta portaria é possível perceber que se recomendava que fosse um mastro de madeira de lei, aquela disponível no lugar, com secção quadrada, contendo na sua parte superior uma "catana" para que fosse reconhecido como tal. Sobre o lugar no qual se levantaria o pelourinho, designa a portaria que os povoadores deveriam escolher a melhor situação. Além de caracterizar a autoridade da vila, o pelourinho é centro geométrico a partir do qual os limites do rossio são demarcados. Tais ritos de fundação delineiam a forma urbana.

Em seguida, o "Extracto para se formar Villa" apresenta as regras para o auto de demarcação da Casa de Câmara e Cadeia:

"E logo no mesmo dia, mes e ano declarados no termo retro nesta nova Villa no Largo que fica em tal parte com tais sinais, aonde foi vindo Fulano comigo escrivão abaixo declarado e sendo aí em presença dos Povoadores, que aí se achavam, se fez exame para se sentar lugar certo, em que se havia de fundar a casa da Câmara e Cadeia, e por todos uniformemente foi assentado, que a melhor paragem era, a em que se achavam, que é o que acima se declara, e de como assim se assentou entre todos, mandou o dito Fulano Lavrar este termo, em que se assinou com os que presentes se achavam: e eu Fulano escrivão, que o escrevi (vão as assinaturas)." (Dom Luiz Antonio de Souza, 1770. Apud ARQUIVO DO ESTADO DE SP, 1894, p.128-9, grifos nossos)

A escolha do local para construir a Casa de Câmara e Cadeia estava a cargo dos moradores da nova vila. Cabia a eles, em comum acordo, escolher o local que thes parecesse mais conveniente.
Quanto à Villa de São Carlos, na mesma data de 14 de dezembro de 1797, tendo sido apregoado o "Auto de Erecção da Villa", foi feito o termo de levantamento do pelourinho, símbolo da autoridade da recém criada vila e demarcado o terreno para a construção do Paço do Concelho e da Cadea. (Figuras 5 e 6). Estes foram implantados em um terreno livre em frente à igreja matriz, articulados no desenho de uma praça (atual Praça Bento Quirino). Para o pelourinho foi mencionado um pau de cabreúva oitavado.

"E logo no mesmo dia mes e ano no ato de Ereção retro declarado nesta Villa de São Carlos, aonde se achava o Doutor Ouvidor geral e Corregedor da Comarca Caetano Luiz de Barros Monteiro commigo Escrivão de seu Cargo adiante nomeado, e sendo aí presentes os moradores desta, e os oficiais da Câmara da Villa de Jundiahy foi escolhido um terreno livre, e desembaraçado de todas as partes, que se acha em distancia bastante da Igreja matriz, e fronteiro a mesma, por parecer - melhor para nele se levantar Pelourinho, e depois de apregoado pelo Porteiro em alta voz, que se levantava o Pelourinho para sinal de Jurisdição, mandou o dito Ministro levantar, o qual é de um pau de Cabreúva oitavado: $E$ aí de fronte do dito Pelourinho se escolheu lugar para os Paços do Concelho, e Cadeia, fincando-se três estacas em sinal, de onde há de principiar a obra, e seguir para a parte da Igreja, ficando de ambos os lados desembarassado de cada parte quarenta palmos para a passagem, e saída do Patio da Matriz, e a Praça do Pelourinho, e para constar, mandou o dito Ministro lavrar este termo de levantamento do Pelourinho, e demarcação do terreno para os Paços do Concelho e Cadea, o qual assinou com o Juiz Presidente e oficiais da Câmara da Villa de Jundiahy e mais pessoas, que presentes se achavam, e eu Vicente Ferreira e Almeida Escrivão da Ouvidoria Geral e Correição o escrevi." (Vicente Ferreira e Almeida, escrivão, 
1797. Apud ARQUIVO DO ESTADO DE

SP, 1913, p.14, grifos nossos)

Figura 5: Planta da Cidade de Campinas, 1878. Destaque para a praça onde foi construída a primeira Igreja Matriz e a Casa de Câmara e Cadeia. FONTE: Centro de Memória, UNICAMP.

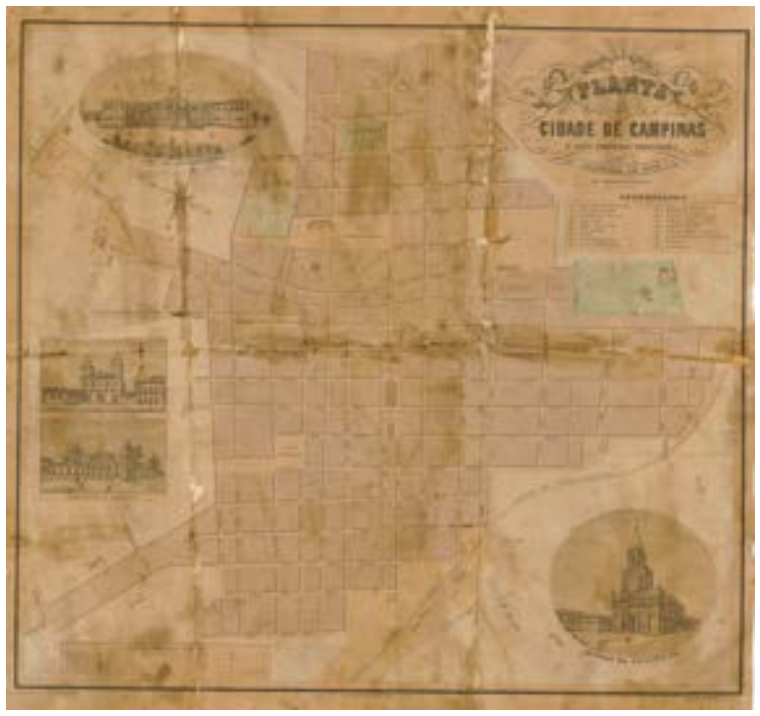

Figura 6: Detalhe da Planta da cidade de Campinas, 1878. O número 5 corresponde ao edifício da primeira Igreja Matriz e o número 7 à Casa de Câmara e Cadeia. FONTE: Centro de Memória, UNICAMP.

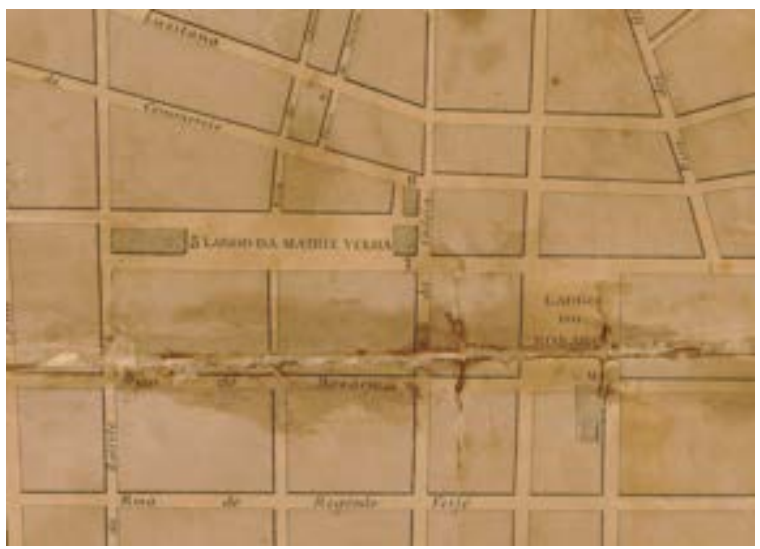

Após o Auto de Ereção da Freguesia de Ararytaguaba a Villa de Porto Feliz, em 22 de dezembro de 1797, o corregedor, diante dos presentes, representantes da câmara da vila de Itu, da nobreza e do povo, procedeu ao termo de levantamento do pelourinho, para o qual foi indicado um pau de cabreúva oitavado, e à demarcação do terreno para os paços do concelho e cadeia:
"(...) foi escolhido um terreno desembaraçado, que se acha na frente da Igreja Matriz desta Villa na Rua direita que vai para o Porto della com distancia muito bastante da Igreja Matriz, e fronteiro a mesma por parecer o melhor para se levantar o Pelourinho, e depois de apregoado pelo Porteiro em alta voz, que naquelle lugar se levantava Pelourinho para signal de jurisdiçam, mandou o dito Ministro levantal-o, o qual hé de cabreuva oitavado: $E$ ahi defronte ao dito Pelourinho, escolheo, e demarcou elle Ministro lugar para os Paços do Concelho e Cadeia, fincando três estacas para signal, de onde hade principiar adita obra, fronteando a mesma rua e correndo ovam para a parte do Cruzeiro distante quarenta palmos e de todos os lados desembarasado para passagem, e servidam dos moradores." (Vicente Ferreira e Almeida, escrivão, 1797. Apud ARQUIVO DO ESTADO DE SP, 1913, p.34, grifos nossos)

No caso da emancipação da Freguesia de Jaguary da Villa de São João de Atibaya, em 1797, os procedimentos foram realizados em duas datas: enquanto o "Auto de Erecção", o "Termo de Levantamento de Pelourinho" e o "Termo de Escolha e de Demarcação de Terreno para os Paços do Concelho e Cadeya" foram realizados no dia 29 de novembro de 1797, o "Termo de Declaração de Rocio", o "Termo de Divisão de Limites" e o "Auto de Eleição" foram realizados no primeiro dia de dezembro de 1797.

Após o "Auto de Erecção" ser declarado na povoação de Jaguary erigindo-a em vila, com anúncio de que esta passaria a se denominar Villa de Nova Bragança, no mesmo dia, ou seja, no dia 29 de novembro de 1797, foi estabelecido o "Termo de Levantamento de Pelourinho", quando "foi escolhido hum terreno livre, e desembaraçado de todas as partes, que se acha nos fundos a Igreja Matriz, por parecer o melhor para nelle se levantar Pelourinho". Na tradição urbana portuguesa, é comum a disposição da Casa de Câmara e Cadeia na 
praça principal da Matriz da vila, na sua frente, ou seja, confrontando-se uma a outra, e entre estas construções o pelourinho. No caso da Villa de Nova Bragança os moradores escolheram um terreno atrás da igreja Matriz por Ihes parecer um terreno mais adequado; cujas especificações espaciais the pareceram mais próprias para tal uso. Em seguida a esta escolha, foi definida a localização do pelourinho e foi indicado um pau de peroba oitavado:

"Depois de apregoado pelo porteiro em alta voz que se levantava o Pelourinho para signal de jurisdição, mandou levantar o dito Ministro nesse lugar para a parte da rua, e principal estrada, o qual hé de hum páo de peroba Oictavado, e para constar mandou lavrar este termo, que assignou com os officiaes da Camara de Atibaya e mais pessoas que presentes se achavam." (Vicente Ferreira e Almeida, escrivão, 1797. Apud ARQUIVO DO ESTADO DE SP, 1895, p.117, grifos nossos)

Os mesmos 34 signatários do "Auto de Erecção" da freguesia a vila assinaram 0 "Termo de Levantamento de Pelourinho".

A demarcação do local onde seria construída a Casa de Câmara e Cadeia era parte do rito de fundação da nova vila, mesmo que a sua construção não se fizesse de imediato e demorasse alguns anos, pois dependeria de recursos financeiros da Câmara. Se a localização da Casa de Câmara e Cadeia, que tradicionalmente era implantada em frente à Matriz, podia apresentar soluções diversas, como no caso da vila da Nova Bragança (ver Figura 8), a localização do pelourinho estava diretamente relacionada com a Casa de Câmara e Cadeia, pois enquanto a primeira era o locus de exercício da nova jurisdição local, o pelourinho era o símbolo desta, e portanto estes dois elementos, definidores do espaço urbano das vilas, tinham suas implantações definidas mutuamente. No mesmo dia de 29 de novembro de 1797 a demarcação do local para a construção da Casa de Câmara e Cadeia foi feita na Villa de Nova Bragança: “...foi escolhido o lugar, onde se levantou o Pelourinho, e defronte delle mandou demarcar com três estacas, que servem para aSinalar o meyo do edifício dos Paços do Concelho, e Cadeya juntamente para a direitura, que há de seguir o edifício, tirada a linha pelas referidas estacas" (Vicente Ferreira e Almeida, escrivão, 1797. Apud ARQUIVO DO ESTADO DE SP, 1895, p.117-8).

Figura 7: Mapa assinalando possíveis quadras da vila de Bragança em 1797 (branco) e em 1835 (cinza). O largo ao fundo da Igreja Matriz foi escolhido para a delimitação da Casa de Câmara e Cadeia. FONTE: Câmara Municipal de Bragança Paulista. Câmara Municipal de Bragança Paulista 1797-1997: Trajetórias e Identidades. Caderno de Memória 2. Bragança Paulista, 1998.

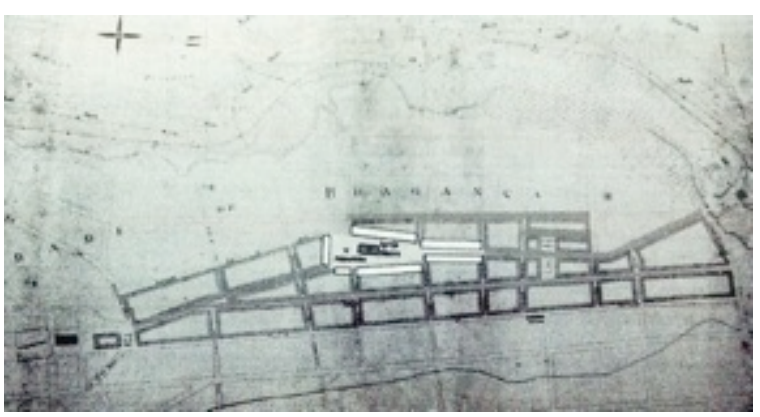

Figura 8: Planta elaborada pelo Engenheiro Nil Andrade Amaral em 1937, usando como base a planta do Engenheiro Arthur Ricci. FONTE: Departamento de Patrimônio da Prefeitura Municipal de Bragança Paulista.

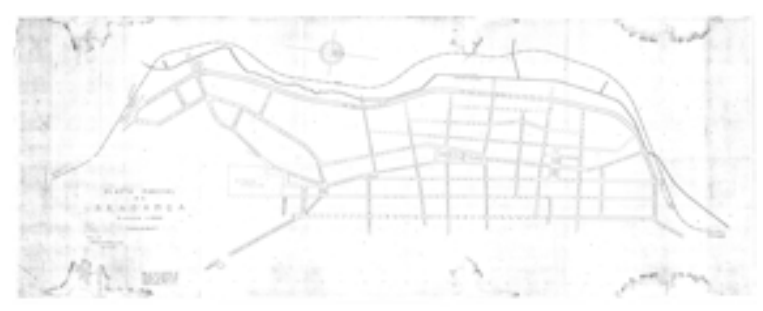

\subsection{Termo de demarcação do rocio da vila}

Após ser "apregoado" em praça pública que aquela freguesia estava erigida em vila e de terem sido firmados o "Termo de Levantamento de Pelourinho" e o "Termo de Escolha e de Demarcação de Terreno para os Paços do Concelho e Cadeia", era necessário redigir o "Termo de Declaração do Rocio", definindo a 
parte do território da nova vila a ser administrada pelo concelho.

O "Extracto para se formar Villa" de 1770, também estabelecia as regras para a formação do rocio.

"Termo de demarcação de terreno para Rocio desta nova villa. E logo no mesmo dia, mes e ano, atrás declarado, aonde se achava presente Fulano comigo Escrivão ao diante nomeado; e sendo aí presentes os Povoadores, que se achavam pelo dito Fulano Ihes foi dito, que era conveniente que esta nova villa ficasse com seu rocio, para Logradouro deles habitantes, e dos mais que para o futuro viessem domiciliar na mesma vila afim de fundar suas casas com quintais, sendo estas formadas, e arruadas na forma que tem determinado o $\mathrm{III}^{\circ}$ e Exm Snr. General desta Capitania; sem pensão alguma de foro, por ser a intenção de Sua Mage, que as terras se povoem, e que a elas se agreguem e se ajuntem aqueles que estão desunidos, e vivendo retirados das mesmas Povoações, devendo todos fazer uniformemente um corpo, e não viverem dispersos, como até agora costumavam neste Estado do Brasil; motivo porque não tem aumento as Povoações; e assim determinou o dito Fulano que o rocio desta villa principiaria do Pelourinho dela um quarto de légua para cada uma das partes de Norte, Sul, Leste, e Oeste, de forma que demarcado este rocio por estas partes, que ficam assim expressas, se mostra ficar em quadra 700 braças, no fim da qual se afincarão marcos de pau de tal para sinal desta divisão, e demarcação, para que dentro dela nenhuma pessoa ocupasse mais do que a casa que fosse precisa para viver com seu quintal; e de como entre todos se assentou estar bem feita esta demarcação do rocio desta villa, para todo o tempo constar, mandou lavrar este termo, em que assignou com os ditos habitantes, e Porteiro, que apregoou, e fez pública a dita divisão: eu e o Fulano escrivão, que o escrevi. (vão as assignaturas)." (Pedro Miz Coimbra, escrivão, 1770. Apud ARQUIVO DO ESTADO DE SP, 1894, p. 129-30, grifos nossos)

O terreno do rocio era destinado à formação da vila, onde poderiam ser construídas casas com quintais para os seus moradores e, no futuro, aquelas para os seus novos habitantes. A delimitação se fazia, segundo o extrato de formação de vila de 1770, a partir do pelourinho, um quadrado com um quarto de léguas em cada uma das quatro faces, norte-sul e lesteoeste. Considerando que, uma légua correspondia a cerca de 6.600 metros, um quarto de légua seria então o equivalente a aproximadamente $1,5 \mathrm{~km}$. A medida final, mencionada como 700 braças corresponde a este quadrado, pois como cada braça equivale a 2,2 metros, teríamos 1.540 metros, ou seja, aproximadamente $1,5 \mathrm{~km}$ entre o pelourinho e cada uma das extremidades norte, sul, leste e oeste da vila. O rocio assim delimitado equivaleria, portanto, a um quadrado de três quilômetros de lado. Em cada um destes pontos equidistantes do pelourinho, deveria ser colocado um marco de madeira para assinalar a demarcação.

O governador recomendava também que os habitantes da vila formassem um "corpo". A população estaria doravante organizada como uma milícia, pronta para a defesa da vila, e cabia ao Capitão-Mor a chefia da mesma. Os recenseamentos populacionais instaurados na Capitania de São Paulo pelo governador D. Luis Antonio de Souza Botelho Mourão, a partir de 1765, registram os "fogos" (residências) e agrupam os moradores em milícias. As casas deveriam ser "arruadas", ou seja, construídas no alinhamento da rua, seguindo normas estabelecidas pelo mesmo governador da capitania. Em princípio, deveria existir em cada vila um arruador, funcionário da câmara, que designava o local da "data" (lote) solicitada pelo morador para construir sua moradia. Era função do arruador fazer o alinhamento desta com as demais casas da rua.

As ordenações de D. Luís Antonio de Souza Botelho Mourão, de 1770, estabeleciam que 
cada morador teria direito apenas a uma casa para sua própria moradia e que não se cobraria foro (imposto recolhido pela Câmara), pois o rei, visando promover o povoamento na capitania de São Paulo, havia assim determinado.

No caso da elevação da freguesia de Jaguary à Villa de Nova Bragança, no primeiro dia de dezembro de 1797, em presença das mesmas pessoas que haviam participado da cerimônia de ereção da vila, de demarcação do termo do pelourinho e dos procedimentos de demarcação dos terrenos para a instalação do concelho e cadeia, ou seja, o Ouvidor Geral e Corregedor da Comarca de São Paulo, Caetano Luiz de Barros Monteiro, o escrivão, Vicente Ferreira de Almeida, os oficiais da Câmara da Villa de São João de Atibaya e os moradores da já configurada Villa de Nova Bragança, foi delimitado o rocio:

“...foi determinado, que o Rocio que devia ter esta Villa, para Logradouro dos habitantes dela, e para fundarem suas casas sem alguma função de foro, era de hum quarto de légua, sendo medido do Pelourinho para quatro Lados, no fim dos quais se poria em cada um seu marco para sinal do limite do dito Rocio, e mandou, que a Câmara, logo, que principiasse a servir mandasse fazer a dita medição, e demarcação na forma referida". (Vicente Ferreira e Almeida, escrivão, 1797. Apud ARQUIVO DO ESTADO DE SP, 1895, p. 118, grifos nossos)

Fica claro que a delimitação do rocio se dava a partir da instalação do pelourinho. O rocio da Villa de Nova Bragança equivaleria também, como o da Villa do Iguatemy, a um quadrado de três quilômetros de lado.

Além de caracterizar a autoridade da vila, o pelourinho é portanto o centro geométrico a partir do qual os limites do rossio são demarcados. Tais ritos de fundação delineiam a forma urbana. No caso da fundação da Villa de São Carlos, este correspondeu a um quadrado de meia légua de lado, delimitando assim as terras atribuídas pela Coroa à res publica, a fim de constituir o patrimônio da câmara. Esta poderia então dividir o rossio em "chãos" (lotes) e concedê-los, com isenção de pagamento dos foros anuais, aos moradores que os pediam para edificar suas casas.

"Aos quinze dias do mez de dezembro de mil settecentos e noventa e sette annos nesta Villa de Sam Carlos Comarca da Cidade de Sam Paulo (...), sendo presentes a Camara da Villa de Jundiahy, e a Nobreza e Povo desta mesma Villa foi determinado que o Rocio que devia ter esta Villa para Logradouro dos habitantes della, e fundarem suas cazas sem aguma pensam de foro era de hum quarto de legoa, sendo medido do Pelourinho para quatro lados, no fim das quaes poria em cada hum seu marco para signal do lemite do dito Rocio, e mandou que a Camara logo principiase a servir, mandasse fazer a dita mediçam, e demarcaçam na forma referida, e para constar mandou lavrar este termo de declarasam de Rocio, (...)." (Vicente Ferreira e Almeida, escrivão, 1797. Apud ARQUIVO DO ESTADO DE SP, 1895, p. 15-6, grifos nossos)

\subsection{O Termo de demarcação dos limites}

Após a delimitação do rocio, seguindo o "Termo de Declaração do Rocio", procedia-se ao "Termo de Divisão de Limites", quando era demarcada a porção do território da vila de origem que seria desmembrada e passaria a constituir o território municipal da vila então criada, com seus limites geográficos e limites confrontantes com as vilas vizinhas. A última etapa era o procedimento do "Auto de Eleição", quando os membros da nova Câmara da vila recém criada eram eleitos, com mandato para administrar a nova vila, geralmente, a partir do ano seguinte.

Além do rossio, que corresponde à porção urbana da vila, o território desta é delimitado pelo termo que corresponde à totalidade das terras controladas pela Câmara. A densidade de ocupação desses territórios era bastante variada, pois "os termos poderiam conter 
arraiais, freguesias e fazendas, mas também sertões residuais mais ou menos extensos, que foram sendo progressivamente colonizados" (FONSECA, 2011, p.30).

A Villa de São Carlos se constituiu a partir da delimitação do seu termo com as demais vilas confinantes, São João de Atibaia, Nova Bragança, Itu, Moji-Mirim e, a partir daquela data, Jundiaí:

"E logo no mesmo dia mes e ano no termo de declaração de rocio retro declarado nesta Villa de São Carlos, Comarca da Cidade de Sam Paulo, (...), que sendo informado pelas pessoas que presentes se achavam, de que as Villas de Sam João de Atibaya, a Nova Bragança, e Mogymirim e Itú, confinantes com esta, se achavam já divididas com seus limites, que Ihes foram dados em suas ereções, vinham os limites desta por essas partes a ser os das mesmas Villas, e que para a parte da Villa de Jundiahy, ficaria sendo seu limite o Córrego da Rocinha, aonde foi o tanque velho do Xavier, e aí na estrada, onde se passa o dito Córrego, mandou se pusesse marco, que servisse de Padrão, para junto a ele se fazer quadra, olhando para esta, e aquela Villa, e daí seguir rumo que der para os lados, (...): E vem a ficar esta vila com cinco léguas de limite para a parte de Mogimirm: Para Itú cinco léguas: Para Jundiahy tres léguas pouco mais ou menos, e para Nova Bragança as que se acharem por não haver informação quantas eram até a divisa com essa Villa: (...), e para constar mandou lavrar este termo, e que se remetessem copias para as Câmeras confinantes, (...)."(Vicente Ferreira e Almeida, escrivão, 1797. Apud ARQUIVO DO ESTADO DE SP, 1895, p. 17-8, grifos nossos)

No caso de Porto Feliz, após a demarcação do rocio, procedeu-se ao termo de demarcação dos limites, ficando a nova vila de Porto Feliz distante duas léguas de Itu, três léguas de Sorocaba e, aproximadamente, dez léguas do rio Piracicaba, limites estes definidos pela hidrografia:

“ (...) o limite desta Villa da parte de Itú chegará até o Ribeirão de Cayacatinga, e descendo por ele abaixo até a sua barra, e defronte a barra seguirá por linha reta até a Furquilha, que estava na Estrada, e correndo por ele abaixo até fazer barra no rio Capivary, e da dita barra ao Salto do Rio Piracicaba, e descendo por ele abaixo de uma, e outra parte até a barra do mesmo rio seguindo o Tietê até o Rio grande e pelo Tietê acima de uma e outra parte até a barra de Sorocaba, e subindo por ele acima da parte esquerda até a barra do Córrego das Areias, e subindo pelo Córrego acima até sua cabeceira, de onde encontrará as cabeceiras de Cayacatinga." (Vicente Ferreira e Almeida, escrivão, 1797. Apud ARQUIVO DO ESTADO DE SP, 1895, p. 35)

Quanto à Villa de Nova Bragança, no primeiro dia de dezembro de 1797, na presença das mesmas pessoas que haviam atendido a delimitação do rocio, em reunião realizada na casa do Ouvidor Geral, foi estabelecido o território pertencente à nova vila, o seu "termo". Para esta delimitação, uma linha imaginária foi traçada procurando estabelecer os limites confrontantes com os seus vizinhos. Principiava esta delimitação pela estrada que ia para Ouro Fino até o "Ribeyrão da Extrema", depois o chamado ribeirão "Camandocaya"; esta linha demarcatória de limites descia por este ribeirão até encontrar a "ponta da Serra Negra", dali descendo pelo "Rio do Peixe" e seguindo pela mesma serra até o "Ribeirão Camandaocaya"; em seguida, este limite descia por este rio abaixo até a "Serra de Craguata" que atravessava a estrada que ia para Mogy-mirim e dali pegava uma direção reta até o "Rio Jaguari"; deste rio ia até a ponta do "morro barreiro", que também era chamado de "Cellado", em direção a "Itapimirim"; a partir deste ponto ia em direção a "Itajupira respeitando a Estrada, que desta Villa vai para 
Atibaya"; a partir deste ponto foi imaginada uma linha reta, na direção do "Vento Nordeste", que ia dar no alto da "Boa Vista" e dali, seguindo o mesmo vento, até o rio "Cachoeira", fazendo a divisa com a Freguesia de Nazareth; esta linha subia este rio acima, até o "Destricto de Minas" e dali seguia "pela Extrema abaixo athé o referido Ribeirão de Camanaocaya", onde ficava a "Guarda de Tolledo" no referido caminho de Ouro Fino. Nesta delimitação ficava esclarecido também, de forma complementar, as distâncias da nova vila em relação aos seus vizinhos, que foram as seguintes: seis léguas de Ouro Fino, dez léguas de Mogymirim e aproximadamente uma légua da Villa de São João de Atibaya. O termo da nova vila, assim delimitado, não possuía precisão, dadas as condições técnicas do período (Vicente Ferreira e Almeida, escrivão, 1797. Apud ARQUIVO DO ESTADO DE SP, 1895, p. 119-20).

\subsection{A eleição da nova Câmara}

Para finalizar a cerimônia de elevação de uma freguesia à condição de vila, se fazia necessário eleger a nova Câmara que passaria a governar a vila recém criada, a partir do ano seguinte. No caso da freguesia de Ararytaguaba, quando elevada a Villa de Porto Feliz, se procedeu à eleição "de pessoas de boas e de sãas consciências, que bem pudessem governar esta Villa". Os 37 votantes elegeram dois juízes, três vereadores e um procurador, que passariam, a partir de 1798 , a governar a nova vila. O escrivão registra ainda em ata, a relação das 69 pessoas que poderiam "servir em Camera" e o número de 572 fogos da freguesia, a partir de então, vila (Vicente Ferreira e Almeida, escrivão, 1797. Apud ARQUIVO DO ESTADO DE SP, 1913, p. 3645).

No mesmo dia, $1^{\circ}$ de dezembro de 1797 , dando sequência à delimitação do termo da Villa de Nova Bragança, procedeu-se à "Elleiçam de Juizes Ordinarios , e mais Officiaes da Camara", que ficou assim composta: dois juízes, três vereadores e um procurador. Para Juízes, foram eleitos o Capitão Lourenço Franco Bueno e o Capitão Antonio Leme da Silva; para Vereadores, o Alferes José Paes da Sylva,
Lourenço Justiniano Freire de Figueiredo e Christovão Xavier do Prado; e para Procurador, João Gomes Ferreira. Dentre estes, o juiz eleito, Antonio Leme da Silva não havia assinado os autos de ereção da vila (Vicente Ferreira e Almeida, escrivão, 1797. Apud ARQUIVO DO ESTADO DE SP, 1895, p. 120-1).

\section{5 - Considerações Finais:}

A análise comparativa das práticas e discursos envolvidos na elevação de freguesias ao estatuto de vila, em 1797, pelo então Governador da capitania de São Paulo Antonio Manoel de Castro e Mendonça (1797-1802), revela como este governo deu continuidade às estratégias de consolidação do território paulista inauguradas pelo governo de Dom Luís Antonio de Souza Botelho Mourão, o Morgado de Mateus (1765-1775). A elevação da vila de Antonina, no atual estado do Paraná, visava consolidar a colonização da baía de Paranaguá pois o litoral sul era uma área vulnerável às aproximações espanholas; a de Jaguary, no território da Vila de Atibaia, estava vinculada aos conflitos e às definições de limites com a Capitania de Minas; a freguesia de Nossa Senhora da Conceição das Campinas do Mato Grosso, então pertencente ao termo da Vila de Jundiaí, importante produtora de açúcar, pela sua posição estratégica no caminho para as minas de Goiás, e Araraytaguaba, pertencente a Itu, também importante produtora de açúcar e porto do Rio Tietê, no caminho para a fronteira com territórios da Espanha. Os procedimentos adotados por Castro e Mendonça revelam a continuidade da política colonizadora ilustrada do período pombalino, que se estende durante a gestão de D. Rodrigo de Souza Coutinho.

Os três estudos de caso pesquisados permitem elucidar que, no final do século XVIII, na Capitania de São Paulo, os processos de elevação das freguesias ao estatuto de vila estavam baseados em um procedimento padronizado, orientado pelo chamado "Auto de Ereção", estabelecendo um rito em conformidade com as Instruções Régias de 1705 e outras ordens posteriormente dirigidas aos Governadores e Capitães Gerais da Capitania. Este processo se iniciava pela 
apresentação, por parte dos moradores, de uma petição, encaminhada ao governador da capitania, na qual estavam expostas as razões que fundamentavam o pedido pela emancipação. Tendo sido autorizado, por portaria do governo a permissão aos moradores para elevar uma freguesia à condição de vila, o ato de fundação da nova vila era uma cerimônia que geralmente ocorria num único dia, com vários procedimentos, sequencialmente planejados, que se desenrolavam na presença de membros do concelho da vila da qual se desmembraria a freguesia em questão, e na presença dos moradores da freguesia que estava se emancipando.

Após ser "apregoado" em praça pública que aquela freguesia estava erigida em vila, os seguintes procedimentos eram, por tradição, conforme as determinações régias, cumpridos: estabelecimento do "Termo de Levantamento de Pelourinho", sinal de jurisdição da vila, e estabelecimento do "Termo de Escolha e de Demarcação de Terreno para os Paços do Concelho e Cadeya". Em seguida, se fazia a delimitação do "Termo de Declaração do Rocio", definindo a parte do território da nova vila a ser administrada pelo concelho. Tais ritos de fundação delineavam a forma urbana. $O$ passo seguinte era o "Termo de Divisão de Limites", registro da porção do território da vila de origem que passava a constituir o território municipal da vila recém criada, com a definição da confrontação com as vilas vizinhas; e, finalmente, o procedimento do "Auto de Eleição", quando a composição da nova câmara da era definida.

Os estudos dos procedimentos de elevação de freguesias a vilas elucidam o processo de constituição do território paulista no final do século XVIII, destacando o papel dos agentes do poder civil e demonstrando que o rito fundacional empregado foi determinante na configuração espacial dos núcleos urbanos em questão.

\section{Referências}

ARQUIVO DO ESTADO DE SP. Documentos Interessantes. Vol. III, (3a edição) "Diversos". São Paulo: Typ. Cardozo Filho \& C., 1913.

ARQUIVO DO ESTADO DE SP. Documentos Interessantes. Vol. VI, "Yguatemy". São Paulo: Typographia da Casa (ao Mercurio), 1894.

ARQUIVO DO ESTADO DE SP. Documentos Interessantes. Vol. XV, "Diversos (homenagens, termos e elevações de vilas)". São Paulo: Escola Typographica Salesiana, 1904.

ARQUIVO DO ESTADO DE SP. Documentos Interessantes. Vol. XXIX, "Correspondência do Capitão-General Antonio Manoel de Mello Castro e Mendonça" (1797-1803). São Paulo: Typographia do Diario Official, 1902.

BELLOTTO, Heloísa Liberalli. Autoridade e conflito no Brasil colonial: o Governo do Morgado de Mateus em São Paulo (1755 1775). São Paulo: Editora Alameda, 2007.

BUENO, Beatriz Piccolotto Siqueira. Delimitação dos confins: caminhos, vilas e cidades na formação da Capitania de São Paulo (1532-1822). Anais do Museu Paulista: História e Cultura Material, São Paulo, v.17, n. 2, p. 251294, jul. - dez. 2009.

CÂMARA MUNICIPAL DE BRAGANÇA PAULISTA. Câmara Municipal de Bragança Paulista 1797-1997: Trajetórias e Identidades. Caderno de Memória 2. Bragança Paulista, 1998.

COSTA, Bruno Aidar. A tessitura do fisco: a politica ilustrada de D. Rodrigo de Souza Coutinho e a administração fiscal da capitania de São Paulo, 1797-1803. 2007. $178 f$. Dissertação (Mestrado em História Econômica) Instituto de Economia da UNICAMP, Campinas, 2007.

DELSON, Roberta Marx. Novas vilas para o Brasil-Colônia. Planejamento espacial e social no século XVIII. Brasília, Ed. Alva-Ciord, 1997.

DERNTL, Maria Fernanda: Método e Arte: criação urbana e organização territorial na capitania de São Paulo 1765-1811. 2010. $225 f$. Tese (Doutorado em Fundamentos da 
Arquitetura e do Urbanismo ) - FAU-USP, São

Paulo, 2010.

FONSECA, Cláudia Damasceno. Arraiais e vilas d`El Rei. Espaço e poder nas Minas setecentistas. Belo Horizonte: Editora UFMG, 2011.

GARRIDO, Felipe de Moura. Produção, comércio e tensões nas vilas do norte da capitania de São Paulo (1788-1808). 2012. 207f. Dissertação (Mestrado em História) Universidade Estadual Paulista Júlio de Mesquita Filho, Franca, 2012.

MARX, Murillo. Cidade no Brasil, terra de quem? São Paulo: EDUSP \& Editora Nobel, 1991.

PETRONE, Maria Thereza Schorer . A Lavoura canaveira em São Paulo - expansão e declínio (1765-1851). São Paulo: Difusão Européia do Livro, 1968.

REIS, Nestor Goulart. As minas de ouro e a formação das Capitanias do Sul. São Paulo: Via das Artes, 2013.

REIS, Nestor Goulart. Contribuição ao Estudo da Evolução Urbana no Brasil (1500-1720). $2^{a}$ ed. São Paulo: Pini, 2001.

REIS, Nestor Goulart. Imagens de vilas e cidades do Brasil Colonial. EDUSP/ Imprensa Oficial do Estado/ FAPESP. São Paulo, 2000.

SALGADO, Ivone; PEREIRA, Renata Baesso. Solução de continuidade no processo de formação de núcleos urbanos da região de Campinas, SP. In: Anais do II ENANPARQ Encontro da Associação Nacional de Pesquisa e Pós-graduação em Arquitetura e Urbanismo, Natal: UFRN, 2012.

SANTOS, Antônio da Costa. Campinas, das origens ao futuro. Compra e venda de terra e água e um tombamento na primeira sesmaria da Freguesia de Nossa Senhora da Conceição das Campinas do Mato grosso de Jundiaí (1732-1992). Campinas: Editora da UNICAMP, 2002. 